\title{
Soil and highbush blueberry responses to fertilization with urea phosphate
}

\author{
Ireneusz Ochmian ${ }^{1 *}$, Jan Oszmiański², Bogusława Jaśkiewicz ${ }^{3}$, \\ Malgorzata Szczepanek ${ }^{4}$
}

\author{
${ }^{1}$ Department of Horticulture \\ West Pomeranian University of Technology in Szczecin, Szczecin, Poland \\ ${ }^{2}$ Department of Fruit and Vegetable Processing \\ Wroclaw University of Environmental and Life Science, Wroclaw, Poland \\ ${ }^{3}$ Department of Cereal Crop Production \\ National Research Institute, Puławy, Poland \\ ${ }^{4}$ Department of Agrotechnology \\ University of Science and Technology, Bydgoszcz, Poland
}

\begin{abstract}
The low availability of soils with an appropriate $\mathrm{pH}$ value (4.2-5.2) is a factor limiting an increase in highbush blueberry acreage. The experiments examined the influence of a physiologically acidic urea phosphate fertilizer on the $\mathrm{pH}$ change of the soil and the mineral content in the soil, leaves, and fruit as well as polyphenols in the fruit of two highbush blueberry cultivars - 'Sunrise' and 'Brigitta Blue'. The fertilizer, at doses of 30 and $60 \mathrm{~kg}$ of nitrogen per hectare, was used in the experiments in each of the three years of the study.

After using $60 \mathrm{~kg} \mathrm{~N} \mathrm{ha}^{-1}$, urea phosphate caused a reduction in soil $\mathrm{pH}$. It also significantly influenced the total soil nitrogen content - the average for the cultivars was $7.40 \mathrm{mg}$ in 2015 , while in the control plots $1.85 \mathrm{mg} 100 \mathrm{~g}^{-1}$. These quantities are above the optimum recommended for highbush blueberry. At the same time, low amounts of this ingredient were found in the leaves ('Sunrise' $-1.83 \mathrm{mg}$; 'Brigitta Blue' $-1.77 \mathrm{mg} 100 \mathrm{~g}^{-1}$ ).

Even after the application of $30 \mathrm{~kg}$ of fertilizer in the second year, the phosphorus content in the soil was at a high level $\left(>4 \mathrm{mg} 100 \mathrm{~g}^{-1}\right)$. The amount of phosphorus also increased in the leaves and fruit. Despite considerable quantities of available magnesium in the soil after urea phosphate application, a significant reduction of this component was observed in the leaves and fruit compared to the unfertilized control bushes. The applied fertilizer reduced the amount of polyphenols in the fruit of the tested cultivars.
\end{abstract}

Keywords: macroelements, phenolics, soil pH, Vaccinium corymbosum

\section{INTRODUCTION}

The shortage of soils that are suitable for highbush blueberry cultivation is a factor limiting an increase in the number of bushes planted and the production of highbush blueberry fruits, both in Poland and in Europe (Chmielewski and Chmielewski, 2010;
Chambers et al., 2013). The highbush blueberry plant forms a shallow root system with almost all roots distributed less than $0.4 \mathrm{~m}$ deep (Bryla and Strik, 2007). The role of exchanging nutrients and water between the plant and soil is fulfilled by fine roots, on the surface of which mycorrhizal fungi develop (Schilder et al., 2002). The bush requires specific

*Corresponding author. 
soils with a low $\mathrm{pH}$ value (Jiang et al., 2017). The $\mathrm{pH}$ of soils determined in $\mathrm{H}_{2} \mathrm{O}$ should fall within the range of 4.2-5.2, but the optimal value ranges from 4.5 to 4.8 (Williamson et al., 2006). Peat soils are the most appropriate for this species, especially highmoor peat or podsolic soils with a stabilized level of groundwater (Starast et al., 2002). Peat bogs are on the decrease all over Europe nowadays (Chmielewski and Chmielewski, 2010; Chambers et al., 2013). This is caused by the draining of areas intended for meadows and croplands, landscape modernization and also mineral mining for heating purposes. Also, other kinds of less suitable soils can be adapted to cultivating highbush blueberry. Usually, their $\mathrm{pH}$ must be changed by using soil sulphurization (Komosa, 2007) or by enriching the soil with acidic peat or sawdust from coniferous trees (Ochmian et al., 2009).

Highbush blueberry cultivars are derived from species of the genus Vaccinium with bushes growing naturally on soils with low nutrient levels. As a result, highbush blueberry fertilization requirements, as compared to other fruit plants, are relatively low (Pormale et al., 2009). Current $\mathrm{N}$ recommendations for blueberry range from 20 to $140 \mathrm{~kg} \mathrm{~N}$ per ha per season, varying with the age of the planting and bush vigour, location, soil type, organic mulching, and inherent soil fertility (Hanson, 2006). Kozinski (2006) obtained higher yields with up to $60 \mathrm{~kg} \mathrm{~N} \mathrm{ha}^{-1}$. On poorer soils the dose can be increased, but it should not exceed $120 \mathrm{~kg}$. Increasing doses of fertilizers cause intense vegetative growth, reducing the yield (Koszański et al., 2008), most likely as a result of ammonium toxicity or salt stress (Banados et al., 2012). Fertilization of highbush blueberry with such high doses of nitrogen is not justified, especially that the assimilation of $\mathrm{N}^{-\mathrm{NO}_{3}}$ ions is quite difficult in an acidic soil (Moro et al., 2017). Also, due to the fast rate of nitrogen transformation to $\mathrm{N}-\mathrm{NO}_{3}$, the fertilizer should be divided into several doses (Krzebietke and Benedycka, 2006).

Plants quickly respond to the lack of available minerals. This has a negative impact on plant growth and development (Ruan et al., 2010). The content of mineral ingredients in the leaves indicates the nutritional condition of the plant. However, it is difficult to define the optimal concentration of mineral ingredients in the soil or leaves. The recommended optimal macronutrient content for highbush blueberry is different depending on the authors (Eck, 1988; Sadowski et al., 1990; Pliszka et al., 1993; Glonek and Komosa, 2006). Pliszka et al. (1993) regarded the nitrogen content in the leaves at $1.3-1.4 \%$ as optimal, while Hanson and Hancock (1996) considered the content of $<1.7 \%$ to be insufficient. Excess of nutrients can also be disadvantageous. Nitrogen can extend the growing season of plants, but in the ammonium form in large amounts it is toxic (Hachiya et al., 2012).

Firmness is one of the most important features of highbush blueberry fruit. It determines the suitability of the fruit for transport and storage, and is mostly determined by the calcium content (Ochmian, 2012; Ochmian et al., 2015b). An increased calcium content in fruits increases firmness, while nitrogen-containing fertilizers reduce it (Ochmian and Kozos, 2015). The use of urea phosphate, especially at a dose of $60 \mathrm{~kg} \mathrm{~N}$ per hectare (1 UP), also causes a reduction in fruit firmness (Kozos and Ochmian, 2016).

The aim of the study was to determine the influence of the application rate of a nitrogenphosphate fertilizer on the $\mathrm{pH}$ value of the soil and on the mineral content in the leaves and fruits of two highbush blueberry cultivars. In addition, its effect on the concentration of polyphenols in the fruit was also measured.

\section{MATERIAL AND METHODS}

\section{Experimental conditions}

The three-year (2013-2015) study was conducted at the Department of Horticulture of the West Pomeranian University of Technology in Szczecin. The research station is located in subzone $7 \mathrm{~A}$ (Heinze and Schreiber, 1984) in the NorthWestern part of Poland in the Szczecin Lowland at a distance of approx. $65 \mathrm{~km}$ from the Baltic Sea $\left(53^{\circ} 40^{\prime} \mathrm{N}, 14^{\circ} 88^{\prime} \mathrm{E}\right)$. The research was conducted on a production plantation specializing in the cultivation of highbush blueberry, located in the Szczecin Lowland. In this area, there are numerous hills of 40-60 $\mathrm{m}$ a.s.l., remnants of the frontal moraine. This affects the distribution of rainfall, the number of sunlight hours, temperature, and wind speed (Tab. 1). The climate of this area is also significantly affected by the presence of large water basins (the Szczecin Lagoon, Lake Dąbie, the Odra River), which provide additional moisture in the period of plant vegetation. The average temperature during the growing season (April-October) between 1951 and 2012 was $13.7^{\circ} \mathrm{C}$, and rainfall $391 \mathrm{~mm}$ (Mijowska et al., 2017). Generally, in May and June of 2015, the temperatures recorded were lower, while in August of 2015 significantly higher, compared 
Table 1. Weather conditions during the vegetative season (April-October) in the years 2013-2015 in relation to the average growing season during the multi-year period (1951-2012)*

\begin{tabular}{|c|c|c|c|c|c|c|c|c|}
\hline \multirow{3}{*}{ Year } & \multicolumn{7}{|c|}{ Month } & \multirow[b]{3}{*}{ Mean } \\
\hline & IV & $\mathrm{V}$ & VI & VII & VIII & IX & $X$ & \\
\hline & \multicolumn{7}{|c|}{ Average temperature $\left({ }^{\circ} \mathrm{C}\right)$} & \\
\hline 2015 & 8.7 & 12.5 & 15.6 & 18.6 & 21.1 & 14.1 & 13.7 & 14.9 \\
\hline 2014 & 10.8 & 13.4 & 16.3 & 21.3 & 17.5 & 15.4 & 11.8 & 15.2 \\
\hline 2013 & 8.4 & 14.4 & 16.9 & 19.3 & 18.7 & 13.0 & 10.9 & 14.5 \\
\hline \multirow[t]{2}{*}{$1951-2012$} & 8.0 & 13.0 & 16.4 & 18.2 & 17.6 & 13.8 & 9.2 & 13.7 \\
\hline & \multicolumn{7}{|c|}{ Rainfall (mm) } & Total \\
\hline 2015 & 29.0 & 48.0 & 32.8 & 62.0 & 14.7 & 34.4 & 22.1 & 242 \\
\hline 2014 & 47.5 & 85.3 & 26.5 & 70.8 & 104.6 & 80.9 & 32.8 & 448 \\
\hline 2013 & 20.8 & 88.1 & 112.5 & 50.4 & 35.9 & 43.9 & 45.8 & 397 \\
\hline $1951-2012$ & 39.7 & 62.9 & 48.2 & 69.6 & 74.2 & 58.7 & 37.3 & 391 \\
\hline
\end{tabular}

*Source: Own work (data from a meteorological station in Ostoja operation within the measurement network of the West Pomeranian University of Technology in Szczecin)

with the years 2013 and 2014 and the mean value for the multi-year period. Additionally, the rainfall during the 2015 growing period was significantly lower in relation to the other experimental years and the mean for the years 1951-2012. The basic weather conditions, such as average temperature and rainfall, during the vegetative season (AprilOctober) in the years 2013-2015 in relation to the multi-year period (1951-2012) had been thoroughly described previously (Mijowska et al., 2016 and 2017).

The plantation in the immediate vicinity of a forest was established on sandy soils - sandy silts, where a natural process of acidification had occurred because of long-term fallow. The organic matter content was $4.1-4.2 \%$ (determined by the weight method of Nelson and Sommers, 1982).

Plants were planted at a spacing of $2.3 \times 1.2 \mathrm{~m}$ on raised beds covered with strips of nonwoven fabric for nurseries, which protected them from weeds. The bushes were watered using a drip-line and the intensity of watering was determined using soil tensiometers - two in one row. Soil moisture was maintained within the optimal range of 10-30 $\mathrm{kPa}$ (IRROMETER Company, Inc)

The fertilization treatments were arranged in a randomized block design with three replicates per treatment. Each treatment plot consisted of one row of 25 plants. The full dose of fertilization was $60 \mathrm{~kg} \mathrm{~N} \mathrm{ha-1} \mathrm{-} 94 \mathrm{~g}$ of urea phosphate per plant (1 UP). Also, the full nitrogen dose reduced by half was applied, i.e. $30 \mathrm{~kg} \mathrm{~N} \mathrm{ha}{ }^{-1}-47 \mathrm{~g}$ of urea phosphate per plant ( $1 / 2$ UP). Plants that grew in the control fields were only irrigated (0 UP - control, without fertilizing $-0 \mathrm{~kg} \mathrm{~N}$ ).
The fertilizer was applied in four equal doses at the beginning of vegetation (bud break - first leaves), at the end of blossoming, during the first ten days of June, and also at the end of June. The fertilizer consisted of $17.7 \% \mathrm{~N}$ and $44.6 \% \mathrm{P}_{2} \mathrm{O}_{5}$ $\left[\mathrm{CO}\left(\mathrm{NH}_{2}\right) \cdot \mathrm{H}_{3} \mathrm{PO}_{4}\right]$. The $\mathrm{pH}$ value of a $10 \%$ solution was 1.2 , with an EC of $34 \mu \mathrm{S} \mathrm{cm}^{-1}$. The fertilizer has a very good solubility in water. The electrical conductivity of the water used for watering was 0.36 $\mu \mathrm{S} \mathrm{cm}^{-1}$, and that of the solution used to fertilize the bushes $-1.4 \mu \mathrm{S} \mathrm{cm}^{-1}$.

Tests were carried out on the cultivars 'Sunrise' and 'Brigitta Blue'. They are very productive cultivars, with large fruits attractive to the consumer. Bushes grow very well and yield annually in the climatic conditions of north-western Poland.

\section{Soil and plant analysis}

Plant and soil material was collected in mid-July. Bulk soil samples were prepared, which were collected from the humus layer $(0-30 \mathrm{~cm})$ using an Egner's sampling stick. The leaves were collected from the central part of one-year-old shoots. Then, they were dried at a temperature of $105^{\circ} \mathrm{C}$. From each harvest (from mid-July to the beginning of August - 'Sunrise'; in August - 'Brigitta Blue'), fruits were taken and stored at a temperature of $-29^{\circ} \mathrm{C}$. For research purposes, the required amount of berries was defrosted.

The $\mathrm{pH}$ of the soil was measured potentiometrically with a CX 742 multifunction meter (ELMETRON, Poland). The estimation of the total mineral content in dry weight was carried out in accordance with the Polish Standard (IUNG, 1972) using certified reagents. After mineralization in 
$\mathrm{H}_{2} \mathrm{SO}_{4}(96 \%)$ and $\mathrm{HClO}_{4}(70 \%)$, the amounts of $\mathrm{N}$, $\mathrm{P}, \mathrm{K}$, and $\mathrm{Mg}$ were estimated in berries and leaves. Soil $\mathrm{K}$ and $\mathrm{P}$ were determined by extracting in $\mathrm{C}_{6} \mathrm{H}_{10} \mathrm{CaO}_{6}$, and the available $\mathrm{Ca}$ and also $\mathrm{Mg}$ by extracting in $\mathrm{C}_{2} \mathrm{H}_{3} \mathrm{O}_{2} \mathrm{NH}_{4}$. Total $\mathrm{N}$ was estimated after mineralization in $\mathrm{H}_{2} \mathrm{SO}_{4}(96 \%)$ and $\mathrm{HClO}_{4}$ (70\%). Nitrogen concentration was determined by the Kjeldahl distillation method using a Gerhardt 30 apparatus. The concentrations of potassium and calcium were measured by atomic emission spectrometry, whereas magnesium content with flame atomic absorption spectroscopy using an iCE 3000 Series spectrometer. Phosphorus content was determined with the Egner-Riehm method at a wavelength of $660 \mathrm{~nm}$, employing a Marcel s 330 PRO spectrophotometer. Tests were performed each year in three replications. Measurements of phenolic compounds in blueberry fruits were performed by the UPLC-PDA-MS method (Mijowska et al., 2016).

\section{Statistical analysis}

A two-factor analysis of variance was performed separately for each cultivar, followed by an assessment of the significance of differences using Tukey's test. The statistical analyses were performed using the Statistica 12.0 software (StatSoft, Polska).

\section{RESULTS AND DISCUSSION}

Nitrogen is the basis for blueberry fertilization (Smolarz, 2009). Ammonia sulfate, urea and highly acidic urea phosphate are the most often recommended fertilizers due to their acidic $\mathrm{pH}$ value and influence on soil acidity (Vargas and Bryla, 2015; Kozos and Ochmian, 2016). Depending on the form of nitrogen $\left(\mathrm{N}-\mathrm{NO}_{3}, \mathrm{~N}-\mathrm{NH}_{4}, \mathrm{~N}-\mathrm{NH}_{2}\right)$, fertilizers are subject to various processes of transformation and have a varying influence on the $\mathrm{pH}$ value of the soil (Diatta and Grzebisz, 2006).

The fertilizer used in the experiment reduced the $\mathrm{pH}$ value of the soil in which the highbush blueberry bushes grew (Tab. 2). The greatest dynamic of changes was observed after the application of $60 \mathrm{~kg}$ $\mathrm{N} \mathrm{ha}^{-1}$ (1 UP). In this case, after three years, the $\mathrm{pH}$ value of the soil was reduced from the initial value of 5.35 (measured in April 2013) to 4.49 ('Sunrise') and 4.68 ('Brigitta Blue'). This is within the range of the optimal soil $\mathrm{pH}$ for highbush blueberry bushes (Williamson et al., 2006; Jiang et al., 2017).

Krzebietke and Benedycka (2006), too, observed a $\mathrm{pH}$ reduction after using urea phosphate. Changes in soil $\mathrm{pH}$ are associated with an increase in the nitrogen content (Ahmed et al., 2006; Butterly et al., 2011). The removal of two $\mathrm{H}+$ ions causes a $\mathrm{pH}$ increase in the rhizosphere during $\mathrm{N}-\mathrm{NO}_{3}$ uptake (von Wiren et al., 2001). Because of the presence of $\mathrm{H}_{3} \mathrm{PO}_{4}$ in its composition, UP causes acidification of the soil environment (Cao et al., 2009).

During 2013-2015, no significant changes were observed in the $\mathrm{pH}$ value in the unfertilized control (0 UP). The experiment showed a significant

Table 2. Changes in the $\mathrm{pH}$ value of soil after fertilization with three levels of Urea-Phosphate (UP) applied over three years to two cultivars. Two methods for determining $\mathrm{pH}$ were used $-\mathrm{in}_{2} \mathrm{H}_{2} \mathrm{O}$ and $\mathrm{KCl}$

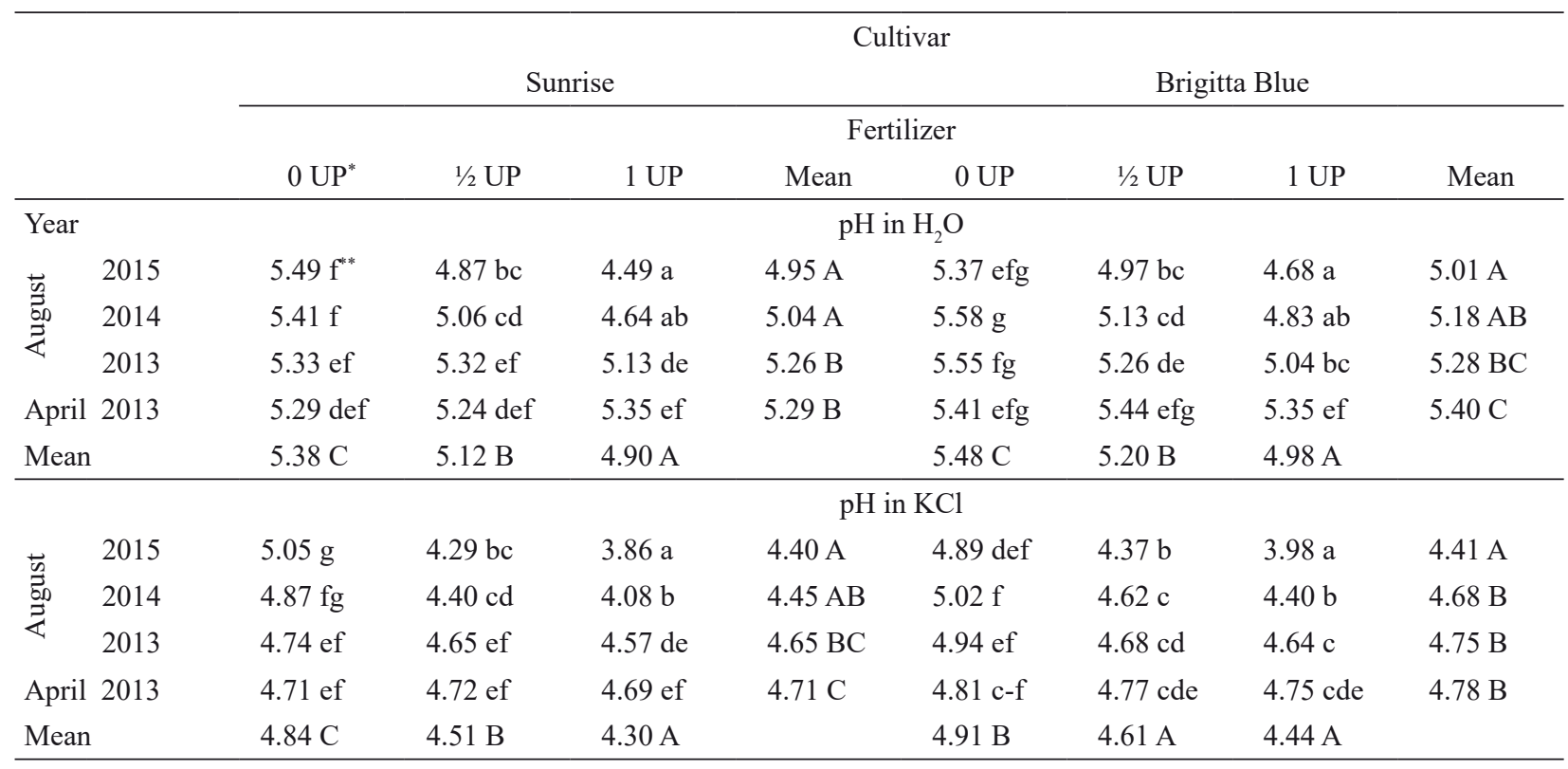

*0 UP $=$ unfertilized, $1 / 2 \mathrm{UP}=30 \mathrm{~kg} \mathrm{~N}^{-1}$, and $1 \mathrm{UP}=60 \mathrm{~kg} \mathrm{~N}$ ha $^{-1}$

** Means followed by the same letter do not differ significantly at $p<0.05$ according to Tukey's multiple range test; lower-case letters indicate interaction and capital letters the main factors 
Table 3. Nitrogen and potassium content in the soil, leaves and fruits after fertilization with three levels of UreaPhosphate (UP) applied over three years to two blueberry cultivars

\begin{tabular}{|c|c|c|c|c|c|c|c|c|}
\hline & \multicolumn{8}{|c|}{ Cultivar } \\
\hline & \multicolumn{4}{|c|}{ Sunrise } & \multicolumn{4}{|c|}{ Brigitta Blue } \\
\hline & \multicolumn{8}{|c|}{ Fertilizer } \\
\hline & 0 UP* & $1 / 2 \mathrm{UP}$ & $1 \mathrm{UP}$ & Mean & $0 \mathrm{UP}$ & $1 / 2 U P$ & $1 \mathrm{UP}$ & Mean \\
\hline Year & \multicolumn{8}{|c|}{ nitrogen in soil - mg $100 \mathrm{~g}^{-1}$ (optimum 2.5-5.0 $0^{\mathrm{a}^{* *}}$ ) } \\
\hline 2015 & $1.97 \mathrm{a}$ & $4.43 \mathrm{~cd}$ & $7.35 \mathrm{f}$ & $4.58 \mathrm{~A}$ & $1.74 \mathrm{a}$ & $4.40 \mathrm{~d}$ & $7.46 \mathrm{~g}$ & $4.53 \mathrm{~B}$ \\
\hline 2014 & $2.31 \mathrm{a}$ & $4.07 \mathrm{bcd}$ & 6.16 ef & $4.18 \mathrm{~A}$ & $1.98 \mathrm{ab}$ & $3.91 \mathrm{~d}$ & $5.77 \mathrm{f}$ & $3.89 \mathrm{AB}$ \\
\hline 2013 & $2.64 \mathrm{ab}$ & $3.56 \mathrm{abc}$ & $5.61 \mathrm{de}$ & $3.94 \mathrm{~A}$ & $2.37 \mathrm{~b}$ & $3.02 \mathrm{c}$ & $5.11 \mathrm{e}$ & $3.50 \mathrm{~A}$ \\
\hline \multirow[t]{2}{*}{ Mean } & $2.31 \mathrm{~A}$ & $4.02 \mathrm{~B}$ & $6.37 \mathrm{C}$ & & $2.03 \mathrm{~A}$ & $3.78 \mathrm{~B}$ & $6.11 \mathrm{C}$ & \\
\hline & \multicolumn{8}{|c|}{ 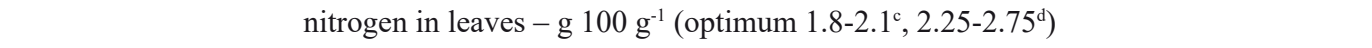 } \\
\hline 2015 & $1.19 \mathrm{ab}$ & $1.64 \mathrm{de}$ & $1.83 \mathrm{e}$ & $1.55 \mathrm{~B}$ & $1.17 \mathrm{ab}$ & $1.48 \mathrm{~cd}$ & $1.77 \mathrm{~d}$ & $1.47 \mathrm{~A}$ \\
\hline 2014 & $1.33 \mathrm{bc}$ & 1.58 cde & $1.77 \mathrm{de}$ & $1.56 \mathrm{~B}$ & $1.12 \mathrm{ab}$ & $1.34 \mathrm{bc}$ & $1.59 \mathrm{~d}$ & $1.35 \mathrm{~A}$ \\
\hline 2013 & $0.96 \mathrm{a}$ & $1.35 \mathrm{bc}$ & $1.52 \mathrm{~cd}$ & $1.28 \mathrm{~A}$ & $1.01 \mathrm{a}$ & $1.26 \mathrm{abc}$ & $1.54 \mathrm{~cd}$ & $1.27 \mathrm{~A}$ \\
\hline \multirow[t]{2}{*}{ Mean } & $1.16 \mathrm{~A}$ & $1.52 \mathrm{~B}$ & $1.71 \mathrm{C}$ & & $1.10 \mathrm{~A}$ & $1.36 \mathrm{~B}$ & $1.63 \mathrm{C}$ & \\
\hline & \multicolumn{8}{|c|}{ 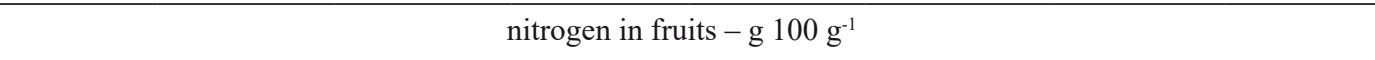 } \\
\hline 2015 & $0.43 \mathrm{bc}$ & $0.52 \mathrm{de}$ & $0.59 \mathrm{e}$ & $0.40 \mathrm{~A}$ & $0.30 \mathrm{ab}$ & 0.44 cde & $0.51 \mathrm{e}$ & $0.42 \mathrm{~B}$ \\
\hline 2014 & $0.38 \mathrm{ab}$ & $0.46 \mathrm{~cd}$ & $0.55 \mathrm{e}$ & $0.46 \mathrm{~B}$ & $0.32 \mathrm{ab}$ & $0.39 \mathrm{bcd}$ & $0.45 \mathrm{de}$ & $0.39 \mathrm{AB}$ \\
\hline 2013 & $0.33 \mathrm{a}$ & $0.37 \mathrm{ab}$ & $0.51 \mathrm{cde}$ & $0.51 \mathrm{~B}$ & $0.26 \mathrm{a}$ & $0.35 \mathrm{abc}$ & $0.44 \mathrm{cde}$ & $0.35 \mathrm{~A}$ \\
\hline \multirow[t]{2}{*}{ Mean } & $0.38 \mathrm{~A}$ & $0.45 \mathrm{~A}$ & $0.55 \mathrm{~B}$ & & $0.29 \mathrm{~A}$ & $0.39 \mathrm{~B}$ & $0.47 \mathrm{C}$ & \\
\hline & \multicolumn{8}{|c|}{ phosphorus in soil - mg $100 \mathrm{~g}^{-1}$ (optimum 2.0-4.0, $3.0-6.0^{\mathrm{b}}$ ) } \\
\hline 2015 & $2.51 \mathrm{ab}$ & $4.78 \mathrm{c}$ & $8.11 \mathrm{e}$ & $5.13 \mathrm{~B}$ & $2.40 \mathrm{a}$ & $5.62 \mathrm{e}$ & $8.93 \mathrm{~g}$ & $5.65 \mathrm{C}$ \\
\hline 2014 & $2.38 \mathrm{ab}$ & $4.39 \mathrm{c}$ & $6.36 \mathrm{~d}$ & $4.38 \mathrm{~B}$ & $2.57 \mathrm{ab}$ & $4.63 \mathrm{~d}$ & $6.94 \mathrm{e}$ & $4.71 \mathrm{~B}$ \\
\hline 2013 & $2.20 \mathrm{a}$ & $3.12 \mathrm{~b}$ & $4.35 \mathrm{c}$ & $3.22 \mathrm{~A}$ & $2.36 \mathrm{a}$ & $3.40 \mathrm{bc}$ & $4.16 \mathrm{~cd}$ & $3.31 \mathrm{~A}$ \\
\hline \multirow[t]{2}{*}{ Mean } & $2.36 \mathrm{~A}$ & $4.10 \mathrm{~B}$ & $6.27 \mathrm{C}$ & & $2.44 \mathrm{~A}$ & $4.55 \mathrm{~B}$ & $6.68 \mathrm{C}$ & \\
\hline & \multicolumn{8}{|c|}{ phosphorus in leaves $-\mathrm{g} 100 \mathrm{~g}^{-1}$ (optimum $0.12-0.40^{\mathrm{c}}, 0.20-0.30^{\mathrm{d}}$ ) } \\
\hline 2015 & $0.08 \mathrm{a}$ & $0.16 \mathrm{bc}$ & $0.23 \mathrm{~cd}$ & $0.16 \mathrm{AB}$ & $0.07 \mathrm{a}$ & $0.15 \mathrm{bc}$ & $0.25 \mathrm{~d}$ & $0.16 \mathrm{~B}$ \\
\hline 2014 & $0.12 \mathrm{ab}$ & $0.19 \mathrm{bcd}$ & $0.26 \mathrm{~d}$ & $0.19 \mathrm{~B}$ & $0.10 \mathrm{ab}$ & $0.16 \mathrm{c}$ & $0.22 \mathrm{~d}$ & $0.16 \mathrm{~B}$ \\
\hline 2013 & $0.13 \mathrm{ab}$ & $0.15 \mathrm{~b}$ & $0.15 \mathrm{~b}$ & $0.14 \mathrm{~A}$ & $0.07 \mathrm{a}$ & $0.12 \mathrm{abc}$ & $0.11 \mathrm{abc}$ & $0.10 \mathrm{~A}$ \\
\hline \multirow[t]{2}{*}{ Mean } & $0.11 \mathrm{~A}$ & $0.17 \mathrm{~B}$ & $0.21 \mathrm{C}$ & & $0.08 \mathrm{~A}$ & $0.14 \mathrm{~A}$ & $0.19 \mathrm{~A}$ & \\
\hline & \multicolumn{8}{|c|}{ 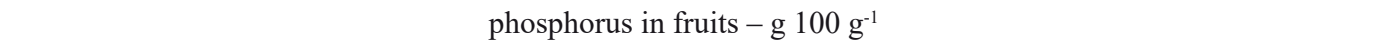 } \\
\hline 2015 & $0.065 \mathrm{a}$ & $0.084 \mathrm{bc}$ & $0.109 \mathrm{~d}$ & $0.086 \mathrm{~A}$ & $0.051 \mathrm{a}$ & $0.094 \mathrm{~cd}$ & 0.113 ef & $0.086 \mathrm{~A}$ \\
\hline 2014 & $0.073 \mathrm{ab}$ & $0.087 \mathrm{bc}$ & $0.098 \mathrm{~cd}$ & $0.086 \mathrm{~A}$ & $0.054 \mathrm{ab}$ & $0.099 \mathrm{cde}$ & $0.121 \mathrm{f}$ & $0.091 \mathrm{~A}$ \\
\hline 2013 & $0.081 \mathrm{abc}$ & $0.095 \mathrm{~cd}$ & $0.112 \mathrm{~d}$ & $0.096 \mathrm{~A}$ & $0.067 \mathrm{~b}$ & $0.088 \mathrm{c}$ & $0.106 \mathrm{de}$ & $0.087 \mathrm{~A}$ \\
\hline Mean & $0.073 \mathrm{~A}$ & $0.089 \mathrm{~B}$ & $0.106 \mathrm{C}$ & & $0.057 \mathrm{~A}$ & $0.094 \mathrm{~B}$ & $0.113 \mathrm{C}$ & \\
\hline
\end{tabular}

*Explanations: see Table 2

**Optimal mineral content of the soil by a Sadowski et al. (1990) and ${ }^{\mathrm{b}}$ Komosa (2007), and in the leaves by ${ }^{\mathrm{c}} \mathrm{Eck}(1988)$ and ${ }^{\mathrm{d}} \mathrm{Bal}$ (1997)

influence of the fertilizer used on the changes in the concentration of the selected minerals in the soil and plants. The soil mineral nitrogen content in the control area (0 UP) was at a low level (Tab. 3). The application of fertilizer caused a significant increase in the nitrogen content in the soil. Fertilization with urea phosphate at a dose of $30 \mathrm{~kg} \mathrm{~N} \mathrm{ha}^{-1}$ caused an increase in the nitrogen content up to the upper limit of the optimal content (2.5-5.0 $\mathrm{mg}$ $\left.100 \mathrm{~g}^{-1}\right)$. A twofold increase in the application of the fertilizer $\left(60 \mathrm{~kg} \mathrm{ha}^{-1}\right)$ substantially increased the soil

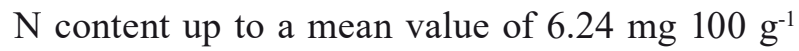

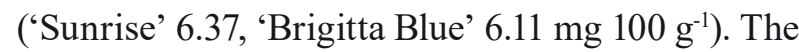
soil $\mathrm{N}$ content changed each year. Despite the high soil $\mathrm{N}$ content, the $\mathrm{N}$ content in the leaves did not reach optimal values - which, according to the cited

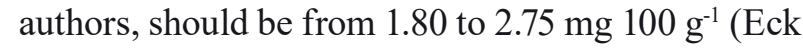
1988; Bal 1997). In Poland, it has been found that the vast majority of highbush blueberry plantations have a low average concentration of available soil 
nutrients (Komosa et al., 2017). This indicates that errors in fertilization or the standards to which we refer need to be corrected or reprocessed. The application of $60 \mathrm{~kg} \mathrm{~N}^{-1}$ (1 UP) increased the leaf $\mathrm{N}$ content in the 'Sunrise' cultivar, but only to the lower limit of the optimal values recommended for highbush blueberry grown in the climatic conditions of the US and Canada (Eck, 1988). The 'Brigitta Blue' cultivar showed a lower leaf $\mathrm{N}$ content, which was below the optimal content. According to Bal's recommendations (1997), the optimal $\mathrm{N}$ content in the leaves should be higher than $2.25 \%$. In other studies, the nitrogen content in the leaves of several highbush blueberry cultivars (Ochmian et al., 2009; Ochmian, 2012; Leitzke et al., 2015), and also of blueberry bushes from an organic plantation in optimal habitat conditions (Strik and Vance, 2015), was also below the optimal level. In the research conducted in Canada by Burkhard et al. (2009), the nitrogen content in the fruit of the cultivar 'Duke' was variable over the years and depended on the cultivation method (mulch application), but it did not exceed $1.52 \%$. The experimental plants did not show any external symptoms of nitrogen

Table 4. Potassium and magnesium content in the soil, leaves and fruits after fertilization with three levels of UreaPhosphate (UP) applied over three years to two blueberry cultivars

\begin{tabular}{|c|c|c|c|c|c|c|c|c|}
\hline & \multicolumn{8}{|c|}{ Cultivar } \\
\hline & \multicolumn{4}{|c|}{ Sunrise } & \multicolumn{4}{|c|}{ Brigitta Blue } \\
\hline & \multicolumn{8}{|c|}{ Fertilizer } \\
\hline & $0 \mathrm{UP} *$ & $1 / 2$ UP & $1 \mathrm{UP}$ & Mean & $0 \mathrm{UP}$ & $1 / 2 \mathrm{UP}$ & $1 \mathrm{UP}$ & Mean \\
\hline Year & \multicolumn{8}{|c|}{ potassium in soil $-\mathrm{mg} 100 \mathrm{~g}^{-1}$ (optimum $5-8^{\mathrm{a}}, 6-8^{\mathrm{b}}$ ) } \\
\hline 2015 & $4.67 \mathrm{a}$ & $5.49 \mathrm{bcd}$ & $5.81 \mathrm{de}$ & $5.32 \mathrm{~A}$ & $5.23 \mathrm{a}$ & $6.07 \mathrm{bc}$ & $6.35 \mathrm{~cd}$ & $5.88 \mathrm{~B}$ \\
\hline 2014 & $5.37 \mathrm{bc}$ & 6.12 ef & $6.78 \mathrm{f}$ & $6.09 \mathrm{~B}$ & $5.96 \mathrm{~b}$ & $6.63 \mathrm{~d}$ & $6.94 \mathrm{e}$ & $6.51 \mathrm{C}$ \\
\hline 2013 & $5.30 \mathrm{~b}$ & $5.68 \mathrm{~cd}$ & $5.47 \mathrm{bcd}$ & $5.48 \mathrm{~A}$ & $5.36 \mathrm{a}$ & $5.46 \mathrm{a}$ & $5.16 \mathrm{a}$ & $5.33 \mathrm{~A}$ \\
\hline \multirow[t]{2}{*}{ Mean } & $5.11 \mathrm{~A}$ & $5.76 \mathrm{~B}$ & $6.02 \mathrm{~B}$ & & $5.52 \mathrm{~A}$ & $6.05 \mathrm{~B}$ & $6.15 \mathrm{~B}$ & \\
\hline & \multicolumn{8}{|c|}{ potassium in leaves $-\mathrm{g} 100 \mathrm{~g}^{-1}$ (optimum $0.35-0.65^{\mathrm{c}}, 0.45-0.75^{\mathrm{d}}$ ) } \\
\hline 2015 & $0.28 \mathrm{a}$ & $0.40 \mathrm{bc}$ & $0.34 \mathrm{ab}$ & $0.34 \mathrm{~A}$ & $0.29 \mathrm{a}$ & $0.37 \mathrm{abc}$ & $0.44 \mathrm{c}$ & $0.37 \mathrm{~A}$ \\
\hline 2014 & $0.32 \mathrm{ab}$ & $0.38 \mathrm{abc}$ & $0.45 \mathrm{c}$ & $0.38 \mathrm{~A}$ & $0.36 \mathrm{abc}$ & $0.41 \mathrm{bc}$ & $0.42 \mathrm{bc}$ & $0.40 \mathrm{~A}$ \\
\hline 2013 & $0.37 \mathrm{abc}$ & $0.35 \mathrm{abc}$ & $0.42 \mathrm{bc}$ & $0.38 \mathrm{~A}$ & $0.33 \mathrm{ab}$ & $0.30 \mathrm{a}$ & $0.39 \mathrm{bc}$ & $0.34 \mathrm{~A}$ \\
\hline \multirow[t]{2}{*}{ Mean } & $0.32 \mathrm{~A}$ & $0.38 \mathrm{AB}$ & $0.40 \mathrm{~B}$ & & $0.33 \mathrm{~A}$ & $0.36 \mathrm{~A}$ & $0.42 \mathrm{~B}$ & \\
\hline & \multicolumn{8}{|c|}{ potassium in fruits $-\mathrm{g} 100 \mathrm{~g}^{-1}$} \\
\hline 2015 & $0.28 \mathrm{ab}$ & $0.25 \mathrm{a}$ & $0.30 \mathrm{ab}$ & $0.28 \mathrm{~A}$ & $0.41 \mathrm{ab}$ & $0.45 \mathrm{ab}$ & $0.44 \mathrm{ab}$ & $0.43 \mathrm{~A}$ \\
\hline 2014 & $0.42 \mathrm{c}$ & $0.38 \mathrm{bc}$ & $0.45 \mathrm{c}$ & $0.42 \mathrm{~B}$ & $0.45 \mathrm{ab}$ & $0.43 \mathrm{ab}$ & $0.48 \mathrm{~b}$ & $0.45 \mathrm{~A}$ \\
\hline 2013 & $0.44 \mathrm{c}$ & $0.43 \mathrm{c}$ & $0.38 \mathrm{bc}$ & $0.42 \mathrm{~B}$ & $0.48 \mathrm{~b}$ & $0.51 \mathrm{~b}$ & $0.32 \mathrm{a}$ & $0.44 \mathrm{~A}$ \\
\hline \multirow[t]{2}{*}{ Mean } & $0.38 \mathrm{~A}$ & $0.35 \mathrm{~A}$ & $0.38 \mathrm{~A}$ & & $0.45 \mathrm{~A}$ & $0.46 \mathrm{~A}$ & $0.41 \mathrm{~A}$ & \\
\hline & \multicolumn{8}{|c|}{ magnesium in soil - mg $100 \mathrm{~g}^{-1}$ (optimum $2.5-4^{\mathrm{a}}, 3-6^{\mathrm{b}}$ ) } \\
\hline 2015 & $3.12 \mathrm{~cd}$ & $2.61 \mathrm{ab}$ & $2.38 \mathrm{a}$ & $2.70 \mathrm{~A}$ & $3.26 \mathrm{c}$ & $2.72 \mathrm{~b}$ & $2.18 \mathrm{a}$ & $2.72 \mathrm{~A}$ \\
\hline 2014 & $3.64 \mathrm{e}$ & $3.40 \mathrm{de}$ & $2.94 \mathrm{bc}$ & $3.33 \mathrm{~B}$ & $3.74 \mathrm{c}$ & $3.35 \mathrm{c}$ & $3.29 \mathrm{c}$ & $3.46 \mathrm{~B}$ \\
\hline 2013 & $3.57 \mathrm{e}$ & $3.16 \mathrm{~cd}$ & 3.23 cde & $3.32 \mathrm{~B}$ & $3.63 \mathrm{c}$ & $3.50 \mathrm{c}$ & $3.36 \mathrm{c}$ & $3.50 \mathrm{~B}$ \\
\hline \multirow[t]{2}{*}{ Mean } & $3.44 \mathrm{C}$ & $3.06 \mathrm{~B}$ & $2.85 \mathrm{~A}$ & & $3.54 \mathrm{~B}$ & $3.19 \mathrm{AB}$ & $2.94 \mathrm{~A}$ & \\
\hline & \multicolumn{8}{|c|}{ magnesium in leaves $-\mathrm{g} 100 \mathrm{~g}^{-1}$ (optimum $0.12-0.25^{\mathrm{c}}, 0.15-0.25^{\mathrm{d}}$ ) } \\
\hline 2015 & $0.14 \mathrm{bc}$ & $0.12 \mathrm{abc}$ & $0.10 \mathrm{ab}$ & $0.12 \mathrm{~A}$ & $0.14 \mathrm{bc}$ & $0.08 \mathrm{a}$ & $0.07 \mathrm{a}$ & $0.10 \mathrm{~A}$ \\
\hline 2014 & $0.17 \mathrm{c}$ & $0.13 \mathrm{abc}$ & $0.10 \mathrm{ab}$ & $0.13 \mathrm{~A}$ & $0.15 \mathrm{c}$ & $0.09 \mathrm{ab}$ & $0.06 \mathrm{a}$ & $0.10 \mathrm{~A}$ \\
\hline 2013 & $0.10 \mathrm{ab}$ & $0.08 \mathrm{a}$ & $0.08 \mathrm{a}$ & $0.09 \mathrm{~A}$ & $0.11 \mathrm{abc}$ & $0.09 \mathrm{ab}$ & $0.07 \mathrm{a}$ & $0.09 \mathrm{~A}$ \\
\hline \multirow[t]{2}{*}{ Mean } & $0.14 \mathrm{~B}$ & $0.11 \mathrm{AB}$ & $0.09 \mathrm{~A}$ & & $0.13 \mathrm{~B}$ & $0.09 \mathrm{~A}$ & $0.07 \mathrm{~A}$ & \\
\hline & \multicolumn{8}{|c|}{ 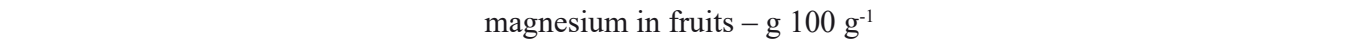 } \\
\hline 2015 & $0.025 \mathrm{ab}$ & $0.023 \mathrm{ab}$ & $0.020 \mathrm{a}$ & $0.023 \mathrm{~A}$ & $0.019 \mathrm{ab}$ & $0.019 \mathrm{ab}$ & $0.017 \mathrm{a}$ & $0.018 \mathrm{~A}$ \\
\hline 2014 & $0.028 \mathrm{~b}$ & $0.026 \mathrm{ab}$ & $0.019 \mathrm{a}$ & $0.024 \mathrm{~A}$ & $0.022 \mathrm{ab}$ & $0.024 \mathrm{~b}$ & $0.018 \mathrm{ab}$ & $0.021 \mathrm{~A}$ \\
\hline 2013 & $0.023 \mathrm{ab}$ & $0.022 \mathrm{ab}$ & $0.025 \mathrm{ab}$ & $0.023 \mathrm{~A}$ & $0.019 \mathrm{ab}$ & $0.017 \mathrm{a}$ & $0.022 \mathrm{ab}$ & $0.019 \mathrm{~A}$ \\
\hline Mean & $0.025 \mathrm{~B}$ & $0.024 \mathrm{AB}$ & $0.021 \mathrm{~A}$ & & $0.020 \mathrm{~A}$ & $0.020 \mathrm{~A}$ & $0.019 \mathrm{~A}$ & \\
\hline
\end{tabular}

***Explanations: see Table 2 and 3 
deficiency, although the nitrogen level in the leaves was low. This confirms the opinion about the low demand for nitrogen by the highbush blueberry plant (Pormale et al., 2009). However, in order to increase productivity, higher doses of fertilizer should be used, e.g. $60 \mathrm{~kg} \mathrm{~N} \mathrm{ha}^{-1}$ (Kozos and Ochmian, 2016). Increased fertilization also had a significant influence on an increase in the nitrogen content in the fruit. Higher nitrogen content was found in the fruit of the cultivar 'Sunrise'. In other studies, the fruit of this cultivar also had a higher nitrogen content compared to 'Brigitta Blue', regardless of the cultivation site. The nitrogen content in the fruit collected from bushes fertilized with 1 UP was similar to that in the unfertilized fruit collected from bushes cultivated under optimal habitat and soil conditions (Strik and Vance, 2015). A significant increase in the nitrogen content in the fruit in other studies was found after the application of nitrogen-containing foliar fertilizers (Ochmian and Kozos, 2015).

The soil phosphorus content increased after the application of 60 and $30 \mathrm{~kg} \mathrm{~N} \mathrm{ha}^{-1}$ of urea phosphate. The phosphorus content in the leaves and fruit of those bushes also increased. Despite the low $\mathrm{pH}$ of the soil, the phosphorus content increased significantly. With such a low soil $\mathrm{pH}$, it was accumulated in limited quantities. However, this form of fertilizer could have an impact on the accumulation of this nutrient by plants, despite the very low soil $\mathrm{pH}$. The interpretation of the results and determination of soil fertility and leaf nutrition level are a problem. The amount of phosphorus in the soil in the control plots was optimal according to Sadowski et al. (1990); however, it was low according to the guidelines provided by Komosa (2007). As a result of full fertilization, the phosphorus content in the soil increased and exceeded the optimal range (3.0-6.0 mg $100 \mathrm{~g} \mathrm{~g}^{-1}$ ) in 2014 and 2015 according to Komosa (2007), but its content in the leaves was optimal according to Eck (1988) and too low according to Bal (1997).

The use of $1 / 2$ UP increased the phosphorus content in the soil to the optimal level; however, its content in the leaves was insufficient according to Bal (1997). The phosphorus content in the leaves was at a level similar to that in the research conducted by Bryla et al. (2012) and Ochmian et al. (2009). According to Eck's recommendation (1988), it is not necessary to use phosphorus fertilization for the cultivars 'Sunrise' and 'Brigitta Blue'. In another experiment, applications of phosphoruspotassium fertilizers over many years had increased the phosphorus content up to $10.6 \mathrm{mg} 100 \mathrm{~g}^{-1}$, which is much higher than the recommended value (Smolarz, 2009). This also considerably reduced the soil $\mathrm{pH}$. During the present experiment, the average value of potassium content in both the control and the fertilized soil fell within the optimal range (Tab. 4). During the first year of the experiment, the magnesium content exceeded the optimal values. However, high concentration of these elements in the soil did not influence their content in the fruits and leaves. Application of the fertilizer significantly reduced $\mathrm{Mg}$ content in both leaves and fruits. The Mg content was reduced below the optimal level specified by both Eck (1988) and Bal (1997). Research by Fageria (2001) showed that $\mathrm{NH}_{4}^{+}$ions inhibit $\mathrm{Mg}$ intake by plants. The $\mathrm{Mg}$ content in the leaves of the control plants was lower than that shown in the research by Bryla et al. (2012) and Ochmian et al. (2010).

Thirty-three phenolic compounds were determined in the analyzed samples. Application of the fertilizer, regardless of the 30 or $60 \mathrm{~kg}$ $\mathrm{N} \mathrm{ha}^{-1}$ dose, contributed to the reduction in the concentration of polyphenols in the fruit of both cultivars (Tab. 5). It was found that there were significantly smaller amounts of anthocyanins and flavonols, particularly after the application of $60 \mathrm{~kg} \mathrm{~N} \mathrm{ha}^{-1}$ (1 UP). The use of the fertilizer lowered the soil $\mathrm{pH}$ to the optimum for highbush blueberry. This could have led to the lower polyphenol content, as was most evidently shown in the last year of the study. Other studies have shown that the fruit harvested from highbush blueberry plants grown under optimal soil conditions contains more polyphenolic compounds (Ochmian et al., 2015a).

The use of nitrogen fertilization causes different responses of blueberry bushes in terms of the concentration of polyphenolic compounds in the fruit (Leitzke et al., 2015). Application of a foliar fertilizer also reduces the amounts of polyphenolic compounds in the fruit (Ochmian and Kozos, 2015). The concentration of polyphenols, especially anthocyanins, is also affected by the size of the fruit. Smaller fruit contains more of these compounds (Ochmian and Kozos, 2014).They are accumulated mainly in the fruit peel and directly underneath it (Fernandez-Pachon et al., 2004). For the same mass (e. g $100 \mathrm{~g}$ ), the surface area of small-fruit peel is much larger than in large fruit. The applied urea phosphate fertilizer increased the yield of the bushes, and the harvested fruits were significantly larger (Kozos and Ochmian, 2016). The concentration of polyphenols varied over the three years of the study. 
Table 5. Concentration of polyphenolic compounds in fruit after fertilization with three levels of Urea-Phosphate (UP) applied over three years to two blueberry cultivars

\begin{tabular}{|c|c|c|c|c|c|c|c|c|}
\hline & \multicolumn{8}{|c|}{ Cultivar } \\
\hline & \multicolumn{4}{|c|}{ Sunrise } & \multicolumn{4}{|c|}{ Brigitta Blue } \\
\hline & \multicolumn{8}{|c|}{ Fertilizer } \\
\hline & 0 UP* & $1 / 2$ UP & $1 \mathrm{UP}$ & Mean & $0 \mathrm{UP}$ & $1 / 2$ UP & $1 \mathrm{UP}$ & Mean \\
\hline Year & \multicolumn{8}{|c|}{ anthocyanins $-\mathrm{mg} 100 \mathrm{~g}^{-1}$} \\
\hline 2015 & $291 \mathrm{c}$ & $257 \mathrm{ab}$ & $224 \mathrm{a}$ & $241 \mathrm{~A}$ & $388 \mathrm{bc}$ & $362 \mathrm{ab}$ & $335 \mathrm{a}$ & $362 \mathrm{~A}$ \\
\hline 2014 & $334 \mathrm{~d}$ & $305 \mathrm{~cd}$ & $276 \mathrm{bc}$ & $291 \mathrm{~B}$ & $559 \mathrm{e}$ & $447 \mathrm{e}$ & $398 \mathrm{c}$ & $468 \mathrm{C}$ \\
\hline 2013 & $252 \mathrm{ab}$ & $270 \mathrm{bc}$ & $244 \mathrm{ab}$ & $257 \mathrm{~A}$ & $432 \mathrm{de}$ & $406 \mathrm{~cd}$ & 449 e & $429 \mathrm{~B}$ \\
\hline Mean & $292 \mathrm{~B}$ & $277 \mathrm{~B}$ & $248 \mathrm{~A}$ & & $460 \mathrm{~B}$ & $405 \mathrm{~A}$ & $394 \mathrm{~A}$ & \\
\hline Year & \multicolumn{8}{|c|}{ phenolic acid - mg $100 \mathrm{~g}^{-1}$} \\
\hline 2015 & $211 \mathrm{bc}$ & $203 \mathrm{bc}$ & $194 \mathrm{abc}$ & $199 \mathrm{~B}$ & $173 \mathrm{~cd}$ & $161 \mathrm{~b}-\mathrm{d}$ & $180 \mathrm{~d}$ & $171 \mathrm{~B}$ \\
\hline 2014 & $183 \mathrm{ab}$ & $170 \mathrm{a}$ & $162 \mathrm{a}$ & $166 \mathrm{~A}$ & $142 \mathrm{ab}$ & $156 \mathrm{bc}$ & $128 \mathrm{a}$ & $142 \mathrm{~A}$ \\
\hline 2013 & $204 \mathrm{bc}$ & $182 \mathrm{ab}$ & $221 \mathrm{c}$ & $202 \mathrm{~B}$ & $165 \mathrm{~cd}$ & $178 \mathrm{~d}$ & $157 \mathrm{bc}$ & $167 \mathrm{~B}$ \\
\hline Mean & $199 \mathrm{~A}$ & $185 \mathrm{~A}$ & $192 \mathrm{~A}$ & & $160 \mathrm{~A}$ & $165 \mathrm{CA}$ & $155 \mathrm{~A}$ & \\
\hline Year & \multicolumn{8}{|c|}{ flavonols - mg $100 \mathrm{~g}^{-1}$} \\
\hline 2015 & $38.9 \mathrm{~cd}$ & $32.5 a b$ & $28.3 \mathrm{a}$ & $33.2 \mathrm{~A}$ & $28.7 \mathrm{bc}$ & $26.8 \mathrm{ab}$ & $24.5 \mathrm{a}$ & $26.7 \mathrm{~A}$ \\
\hline 2014 & $42.2 \mathrm{cde}$ & $37.8 \mathrm{bc}$ & $36.6 \mathrm{bc}$ & $38.9 \mathrm{~B}$ & $35.6 \mathrm{e}$ & $31.5 \mathrm{~cd}$ & $28.4 \mathrm{abc}$ & $31.8 \mathrm{~B}$ \\
\hline 2013 & $42.5 \mathrm{cde}$ & $45.1 \mathrm{e}$ & $43.6 \mathrm{de}$ & $43.7 \mathrm{~B}$ & $37.8 \mathrm{ef}$ & $39.7 \mathrm{f}$ & $34.4 \mathrm{de}$ & $37.3 \mathrm{C}$ \\
\hline Mean & $41.2 \mathrm{~B}$ & $38.5 \mathrm{AB}$ & $36.2 \mathrm{~A}$ & & $34.0 \mathrm{~B}$ & $32.7 \mathrm{~B}$ & $29.1 \mathrm{~A}$ & \\
\hline Year & \multicolumn{8}{|c|}{ flavan-3-ols - mg $100 \mathrm{~g}^{-1}$} \\
\hline 2015 & $40.3 \mathrm{c}$ & $37.0 \mathrm{c}$ & $31.5 \mathrm{ab}$ & $36.3 \mathrm{~B}$ & $53.4 \mathrm{~d}$ & $45.1 \mathrm{~b}$ & $42.9 \mathrm{a}$ & $47.1 \mathrm{~A}$ \\
\hline 2014 & $48.6 \mathrm{de}$ & $45.4 \mathrm{~d}$ & $51.3 \mathrm{e}$ & 48.4 B & $61.2 \mathrm{e}$ & $50.3 \mathrm{~cd}$ & $52.4 \mathrm{~d}$ & $54.6 \mathrm{~B}$ \\
\hline 2013 & $32.7 \mathrm{ab}$ & $29.8 \mathrm{a}$ & $33.6 \mathrm{~b}$ & $32.0 \mathrm{~A}$ & $44.5 \mathrm{~b}$ & $48.9 \mathrm{c}$ & $47.4 \mathrm{bc}$ & $46.9 \mathrm{~A}$ \\
\hline Mean & $40.5 \mathrm{~B}$ & $37.4 \mathrm{~A}$ & $38.8 \mathrm{AB}$ & & $53.0 \mathrm{~B}$ & $48.1 \mathrm{~A}$ & $47.6 \mathrm{~A}$ & \\
\hline Year & \multicolumn{8}{|c|}{ total $-\mathrm{mg} 100 \mathrm{~g}^{-1}$} \\
\hline 2015 & $581 \mathrm{c}$ & $530 \mathrm{~b}$ & $478 \mathrm{a}$ & $530 \mathrm{~A}$ & $651 \mathrm{~b}$ & $600 \mathrm{a}$ & 592 a & $614 \mathrm{~A}$ \\
\hline 2014 & $608 \mathrm{c}$ & $558 \mathrm{~b}$ & $526 \mathrm{~b}$ & $564 \mathrm{~B}$ & $790 \mathrm{c}$ & $680 \mathrm{~b}$ & $597 \mathrm{a}$ & $689 \mathrm{~B}$ \\
\hline 2013 & $531 \mathrm{~b}$ & $527 \mathrm{~b}$ & $542 \mathrm{~b}$ & $533 \mathrm{~A}$ & $679 \mathrm{~b}$ & $673 \mathrm{~b}$ & $688 \mathrm{~b}$ & $680 \mathrm{~B}$ \\
\hline Mean & $573 \mathrm{~B}$ & $538 \mathrm{~A}$ & $515 \mathrm{~A}$ & & $707 \mathrm{~B}$ & $651 \mathrm{~A}$ & $626 \mathrm{~A}$ & \\
\hline
\end{tabular}

****xplanations: see Table 2 and 3

Their highest level was found in the fruit in 2014, when the weather was extremely hot and rainy in July, followed by a cool and rainy period in August (Tab. 1). The effects of weather on the amounts of polyphenolic compounds have also been reported by other authors (Wawro et al., 2013). Plants which are grown at a low temperature generally contain smaller amounts of phenolic acid, flavonols, and anthocyanins (Wang and Zheng, 2001).

\section{CONCLUSIONS}

1. Regardless of the fertilizer dose, urea phosphate resulted in a significant reduction in soil $\mathrm{pH}$.

2. The twofold increase in fertilization rate $(60 \mathrm{~kg}$ $\mathrm{N}$ per hectare) significantly increased the soil $\mathrm{N}$ content to a level higher than the optimum level recommended for blueberry production. However, the leaf $\mathrm{N}$ remained low. The soil $\mathrm{P}$ content increased after the application of the fertilizer. The P content in the leaves and fruit also increased. Despite the considerable soil $\mathrm{Mg}$ content, the leaf and fruit $\mathrm{Mg}$ concentrations were substantially reduced by the application of urea phosphate fertilization.

3. Reducing the soil $\mathrm{pH}$ to the optimum for the cultivation of highbush blueberry decreased the fruit polyphenol content.

\section{FUNDING}

This work was supported by the Polish Ministry of Science and Higher Education No. N N310 205337. 


\section{AUTHOR CONTRIBUTIONS}

I.O., M.S. and B.J. - contributed to the entire experimental process, chemical and data analyses, interpretation, literature search and writing; J.O. - was involved in the determination of polyphenolic compounds.

\section{CONFLICT OF INTEREST}

Authors declare no conflict of interest.

\section{REFERENCES}

Ahmed O.H., Aminuddin H., Husni M.H.A., 2006. Reducing ammonia loss from urea and improving soil exchangeable ammonium retention through mixing triple superphosphate, humic acid and zeolite. Soil Use Manage. 22(3), 315-319.

BAL J.J.M., 1997. Blueberry culture in greenhouses, tunnels, and under raincovers. Acta Hortic. 446, 327331.

Banados M., Strik B., Bryla D., Righetti T., 2012. Response of highbush blueberry to nitrogen fertilizer during field establishment, I: accumulation and allocation of fertilizer nitrogen and biomass. HortScience 47(5), 648-655.

Bryla D., Strik B., 2007. Effects of cultivar and plant spacing on the seasonal water requirements of highbush blueberry. J. Am. Soc. Hortic. Sci. 132(2), 270-277.

Bryla D., Strik B., Bañados M., Righetti T., 2012. Response of highbush blueberry to nitrogen fertilizer during field establishment - II. Plant nutrient requirements in relation to nitrogen fertilizer supply. HortScience 47(7), 917-926.

Burkhard N., Lynch D., Percival D., Sharifi M., 2009. Organic mulch impact on vegetation dynamics and productivity of highbush blueberry under organic production. HortScience 44(3), 688-696.

Butterly C.R., Bhatta Kaudal B., Baldock J.A., TANG C., 2011. Contribution of soluble and insoluble fractions of agricultural residues to short term $\mathrm{pH}$ changes. Eur. J. Soil Sci. 62(5), 718-727.

CaO X., Wahbi A., Ma L., Li B., Yang Y., 2009. Immobilization of $\mathrm{Zn}, \mathrm{Cu}$, and $\mathrm{Pb}$ in contaminated soils using phosphate rock and phosphoric acid. J. Hazard. Mater. 164(2-3), 555-564.

Chambers F., Cloutman E., Daniell J., Mauquoy D., Jones P., 2013. Long term ecological study (palaeoecology) to chronicle habitat degradation and inform conservation ecology: an exemplar from the Brecon Beacons, South Wales. Biodivers. Conserv. 22,719 .

Chmielewski T., Chmielewski S., 2010. The process of lake and bog ecosystems disappearance in the region of Polesie National Park since the second half of XX ct. and the prospects of their protection. Probl. Ekol. Kraj. XXVI, 121-134.
Diatta J., Grzebisz W., 2006. Influence of mineral nitrogen forms on heavy metals mobility in two soils. Pol. J. Environ. Stud. 15(2a), 56-62.

EcK P., 1988. Blueberry science. Plant Nutrition, Rutgers University Press, New Brunswick, N.J., 93159.

FAGERIA V., 2001. Nutrient interactions in crop plants. J. Plant Nutr. 24(8), 1269-1290.

Fernandez-Pachon M., Villano D., Garcia-Parrilla M., Troncoso A., 2004. Antioxidant activity of wines and relation with their polyphenolic composition. Anal. Chim. Acta 513, 113-118.

GloneK J., Komosa A., 2006. The effect of fertigation on the nutrient status and yield of highbush blueberry cv. Bluecrop. Acta Hortic. 715, 371-374.

Hachiya T., Watanabe C., Fujimoto M., Ishikawa T., Takahara K., Kawai-Yamada M., Uchimiya H., Uesono Y., Terashima I., Noguchi K., 2012. Nitrate addition alleviates ammonium toxicity without lessening ammonium accumulation, organic acid depletion and inorganic cation depletion in Arabidopsis thaliana shoots. Plant Cell. Physiol. 53, 577-591.

Hanson E., Hancock J., 1996. Managing highbush blueberry nutrition. MSUE Bull. E-2011, 1-13.

HANSON E.J. 2006. Nitrogen fertilization of highbush blueberry. Acta Hortic. 715, 347-351.

Heinze W., Schreiber D. 1984. Eine neue Kartierung der Winterhärte-Zonen für Gehölze in Europa. Mittelungen der Deutschen Dendrologischen Gesellschaft, 75, 11-56.

IUNG., 1972. Methods of laboratory tests in chemical laboratories. Part II. The study of plant material. IUNG Puławy, 25-83 (in Polish).

JiAng Y., Li Y., Zeng Q., Wei J., Yu H., 2017. The effect of soil $\mathrm{pH}$ on plant growth, leaf chlorophyll fluorescence and mineral element content of two blueberries. Acta Hortic. 1180, 269-276.

Komosa A., 2007. Guide values and soil nutrient contents of highbush blueberry (Vaccinium corymbosum L.) plantations in Poland. Int. Conf. "Vacciniun ssp. and Less Known Small Fruits: Cultivation and Health Benefit". Slovak Akademy of Science, Nitra, 30.095.10.2007, 29-30.

Komosa A., RoszyK J., Mieloch M., 2017. Content of nutrients in soils of highbush blueberry (Vaccinium corymbosum L.) plantations in poland in a long-term study. J. Elem. 22(4), 1193-1207.

Koszański Z., Rumasz-Rudnicka E., Friedrich, S., 2008. Anatomy, morphology and yield of highbush blueberry (Vaccinium corymbosum L.) under the influence of irrigation and mineral fertilisation. Acta Agrophys. 11(3), 677-684.

KozINSKI B., 2006. Influence of mulching and nitrogen fertilization rate on growth and yield of highbush blueberry. Acta Hortic. 715, 231-235.

Kozos K., Ochmian I., 2016. The influence of fertilisation urea phosphate on growth and yielding bush of two 
highbush blueberry cultivars ( $V$. corymbosum). Folia Pomer. Univ. Technol. Stetin. Agric., Aliment., Pisc., Zootech. 325(37)1, 29-38.

Krzebietke S., Benedycka Z., 2006. The influence of urea phosphate on the physicochemical properties of peat substrate under laboratory conditions. Acta Agrophys. 7(4), 969-976.

Leitzke L.N., Picolotto L., dos Santos Pereira I., Vignolo G.K., Schmitz J.D., Vizzotto M., et al., 2015. Nitrogen fertilizer affects the chemical composition of the substrate, the foliar nutrient content, the vegetative growth, the production and fruit quality of blueberry. Científica 43(4), 316324.

Mijowska, K., Ochmian, I., Oszmiański, J., 2016. Impact of cluster zone leaf removal on grapes cv. Regent polyphenol content by the UPLC-PDA/MS method. Molecules 21(12), 1688.

Mijowska K., Ochmian I., Oszmiański J., 2017. Rootstock effects on polyphenol content in grapes of 'Regent'cultivated under cool climate condition. J. Appl. Bot. Food Qual. 90, 159-164.

Moro E., Crusciol C.A.C., Nascente A.S., Cantarella H., Broetto F., Moro A. L. 2017. Nitrate reductase, micronutrients and upland rice development as influenced by soil $\mathrm{pH}$ and nitrogen sources. Commun. Soil Sci. Plant Anal. 48(22), 2642-2651.

Nelson D., Sommers L., 1982. Total carbon, organic carbon, and organic matter. In: Methods of soil analysis. Part 2. Chemical and microbiological properties. A.L. Page, R.H. Miller and D.R. Keeney (Eds), American Society of Agronomy and Soil Science Society of America, Madison, USA, 539579.

OCHMIAN I., 2012. The impact of foliar application of calcium fertilizers on the quality of highbush blueberry fruits belonging to the 'Duke' cultivar. Not. Bot. Horti. Agrobot. Cluj Napoca 40(2), 163-169.

Ochmian I., Grajkowski J., Mikiciuk G., Ostrowska K., CheŁpiński P., 2009. Mineral composition of high blueberry leaves and fruits depending on substrate type used for cultivation. J. Elem. 14(3), 509516.

Ochmian I., Grajkowski J., Skupień K., 2010. Effect of substrate type on the field performance and chemical composition of highbush blueberry cv. Patriot. Agr. Food Sci., 19, 69-80.

Ochmian I., Kozos K., 2014. Fruit quality of highbush blueberry (Vaccinium corymbosum L.) cv. 'Duke'depending on the method of cultivation. Folia Pomer. Univ. Technol. Stetin. Agric., Aliment., Pisc., Zootech. 312(31), 117-126

Ochmian I., Kozos K., 2015. Influence of foliar fertilisation with calcium fertilisers on the firmness and chemical composition of two highbush blueberry cultIvars. J. Elem. 20(1), 185-201.

Ochmian I., Kozos K., Chelpiński P., Szczepanek M., 2015a. Comparison of berry quality in highbush blueberry cultivars grown according to conventional and organic methods. Turk. J. Agric. For. 39(2), 174181.

Ochmian I., Kozos K., MijowsKa K., 2015b. Influence of storage conditions on changes in physical parameters and chemical composition of highbush blueberry (Vaccinium corymbosum L.) fruit during storage. Bulg. J. Agric. Sci. 21(1), 178-183.

Pliszka K., Scibisz K., RoJeK H., 1993. The effect of soil management and mineral fertilization upon growth and cropping of the highbush blueberry cv. Bluecrop. Acta Hortic. 346, 147-152.

PN-R-04028, 1997. Agrochemical soil analysis - determination of nitrate and ammonium ions in the mineral soils. Polish standard. Polish Committee for Standardization, Warsaw (in Polish), December, $1-5$.

Pormale J., Osvalde A., Nollendorfs V., 2009. Comparison study of cultivated highbush and wild blueberry nutrient status in producing plantings and woodlands. Latvian J. Agron. 12, 80-87.

Ruan J., Haerdter R., GerendÁs J., 2010. Impact of nitrogen supply on carbon/nitrogen allocation: a case study on amino acids and catechins in green tea Camellia sinensis (L.) O. Kuntze plants. Plant Biol. 12, 724-734.

Sadowski A., Nurzyski J., Pacholak E., Smolarz K., 1990. Określenie potrzeb nawożenia roślin sadowniczych. II Zasady, Liczby Graniczne i Dawki Nawożenia. Instrukcja Upowszechnieniowa nr 3. SGGW, 25.

Schilder A.M.C., Olatinwo R.O., Hanson E.J., 2002. Fruit rots are common in commercial cranberry beds in Michigan, USA. Acta Hortic. 574, 91-93.

SMOLARz K., 2009. Short information about the history of the commercial cultivation highbush blueberry in Poland. Agronomijas Vēstis. 12, 119-122.

Starast M., Karp K., PaAl T., 2002. The effect of using different mulches and growth substrates on half-highbush blueberry (Vaccinium corymbosum $\times V$. angustifolium) cultivars 'Northblue' and 'Northcountry'. Acta Hortic. 574, 281-286.

Strik B., VAnce A., 2015. Seasonal variation in leaf nutrient concentration of northern highbush blueberry cultivars grown in conventional and organic production systems. HortScience 50(10), 1453 -1466 .

VARgas O.L., Bryla D.R., 2015. Growth and fruit production of highbush blueberry fertilized with ammonium sulfate and urea applied by fertigation or as granular fertilizer. HortScience 50(3), 479-485.

von Wiren N., Gojon A., Chaillou S., Raper JR D., 2001. Mechanisms and regulation of ammonium uptake in higher plants. In: Plant Nitrogen. P.J. Lea and J.-F.s Morot-Gaudry (Eds), Springer-Verlag Berlin Heidelberg, 61-77. 
WANG S., ZHENG W., 2001. Effect of plant growth temperature on antioxidant capacity in strawberry. J. Agric. Food Chem. 49(10), 4977-4982.

Wawro, A., Pieprzyk-Kokocha D., Gryszczyńska A., Łowicki Z., Mikolajczak P., Grajek K., 2013. Comparison of the composition of the polyphenol content in the hydroalcoholic extracts leaves of different varieties of white mulberry (Morus alba L.). Post. Fitoter. 4, 220-224.
Williamson J., Krewer G., Pavlis G., Mainland C., 2006. Blueberry soil management, nutrition and irrigation. In: Blueberries for Growers, Gardeners and Promoters. N.F. Childers and P.M. Lyrene (Ed.), E.O. Gainesville, Fl, USA, 60-74.

Received June 6, 2017; accepted April 6, 2018 